\title{
Synthesis, in-silico Studies and Evaluation of Anticancer Activity of Some Novel Benzothiazole Substituted 4-Thiazolidinones
}

\author{
Chaithra Raju Shetty ${ }^{1}$, Katte Ishwar Bhatt, ${ }^{1, *}$ Abhishek Kumar ${ }^{1}$, Pankaj Kumar ${ }^{1}$, Praveen Thaggikuppe \\ Krishnamurthy ${ }^{2}$, Vijay Kumar Merugumolu ${ }^{3}$
}

${ }^{1}$ Department of Pharmaceutical Chemistry, NGSM Institute of Pharmaceutical Sciences, NITTE (Deemed to be University), Paneer, Mangaluru, Karnataka, INDIA.

${ }^{2}$ Department of Pharmacology, JSS College of Pharmacy, Ooty, The Nilgiris, Tamil Nadu, INDIA.

${ }^{3}$ Department of Pharmacology, NGSM Institute of Pharmaceutical Sciences, NITTE (Deemed to be University), Paneer, Mangaluru, Karnataka, INDIA.

\begin{abstract}
Background: Cancer is one of the leading diseases associated with the high degree of mortality. In current scenario chemotherapy is the major treatment for cancer and it still has few limitations. The continuous seek for highly effective and safe anticancer agents is the one of the major goal for medicinal chemists. Objectives: In the present work, the hybrid molecule i.e benzothiazole substituted 4-thiazolidinone has been synthesized and evaluated for anticancer activity. Methods: A series of novel benzothiazole substituted 4-thiazolidinone derivatives were synthesized by reacting 2-amino-6-methyl benzothiazole with aromatic aldehydes in alcoholic media, resulting schiff bases are made to react with thioglycolic acid in dioxane. Characterization of synthesized compounds were done by IR, ${ }^{1} \mathrm{H}$ NMR, Mass spectroscopy. In silico studies with molecular docking was performed for the synthesized derivatives by taking proteins from PDB i.e VEGFR-2 kinase and Human thymidylate synthase (PDB ID:20U5 and 5HS3) as the targets. Results and Discussion: Based on the docking score, best four compounds were selected and screened for in-vitro anticancer activity. From the in-vitro data, finally one potential molecule was selected and evaluated for in-vivo cytotoxic activity. Conclusion: All 4 screened derivatives were found to show good cytotoxic activity, out of which P14 can be considered as promising molecule.
\end{abstract}

Key words: Benzothiazole, 4-Thiazolidinone, Anticancer, In silico, Docking.

\section{INTRODUCTION}

Cancer is one of the fatal diseases associated with the high degree of mortality preceded by cardiovascular and infectious diseases. ${ }^{1,2}$ Chemotherapy, is one of the major treatment for malignancies, but it is associated with few limitations like lack of selectivity and sensitivity, unwanted and serious adverse effect and acquisition of resistance to the multiple drugs. ${ }^{3,4}$

In recent years galaxy of heterocyclic compounds are gaining importance due to their useful biological and pharmacological properties. ${ }^{5}$ In the present work, the hybrid molecule i.e benzothiazole substituted 4-thiazolidinone has been taken. Design and development of novel molecules based on privileged scaffolds may be the successful directions in drug discovery.

4-thiazolidinones are considered as the important heterocyclic molecule in the field of medicinal chemistry because of its selectivity and affinity towards different biotargets related to cancer which is the most important criteria in drug discovery. ${ }^{6}$ They exhibit different activities like antibacterial, antitubercular, antifungal, antiviral (anti-HIV mainly), anticonvulsant, antidiabetic, antiinflammatory and analgesic, antiparasitic,
Submission Date: 23-06-2020; Revision Date: 25-08-2020; Accepted Date: 23-10-2020

DOI: 10.5530/ijper.54.4.208 Correspondence: Dr. K Ishwar Bhat Professor and HoD, Department of Pharmaceutical Chemistry, NGSM Institute of Pharmaceutical Sciences

Paneer, Deralakatte, Mangalore-575018,

Karnataka, INDIA.

Phone no:

+91-9901318227

Email id: bhatishwark@nitte. edu.in

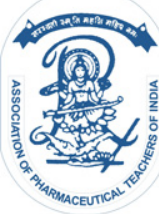

www.ijper.org 
antihypertensive, antihyperlipidemic, MAO inhibitors and anticancer activity.?

Benzothiazole is a bicyclic ring system contains a benzene ring fused to a thiazole ring. Benzothiazole is considered as one of the contemplate nucleus in medicinal chemistry which exhibits different types of pharmacological actions such as antimicrobial, anthelmintic, antiviral, antileishmanial, fungicidal, antibacterial, antirheumatic, antituberculotic, antiinflammatory, CNS depressant, antitumor properties. ${ }^{8}$ As both molecules are known with wide diverse biological profile including anticancer properties, it gained our interest to make hybrid molecule by considering these two parent nucleus with different substitution on the phenyl ring present on the $2^{\text {nd }}$ position of the 4-thiazolidinone moiety, which is expected to enhance the anticancer properties of resulting molecule. So, in the current study we planned to synthesize some novel benzothiazole incorporated 4-thiazolidinones with various substitution on the phenyl ring and we were curious to evaluate their anticancer potential by in-vitro and in-vivo models.

\section{MATERIALS AND METHODS}

\section{Experimental study}

All the reactions were carried out under specified laboratory conditions. All the synthetic work was done by procuring laboratory grade reagents and analytical grade solvents procured from Hi media, $\mathrm{CDH}$ and Sigma Aldrich. The products were purified by recrystallization using suitable solvents. Melting points were determined by digital melting point apparatus and were uncorrected. Characterization was done by IR, NMR and Mass spectroscopy. IR spectra was recorded by using Alpha Bruker IR spectrometer in $\mathrm{KBr}$ discs $\left(\mathrm{cm}^{-1}\right)$. ${ }^{1} \mathrm{H}-\mathrm{NMR}$ spectra was measured in DMSO- $\mathrm{d}_{6}$ as solvent on Bruker Avance-II $300 \mathrm{MHz}$ NMR spectrometer using TMS as internal standard. Chemical shift values are reported as values in ppm relative to TMS $(\delta=0)$. Mass spectrum was recorded on SYNAPT-G2 LC-MS spectrometer.

\section{Synthesis of benzothiazole substituted 4-Thiazolidinones}

The synthesis involves following steps:

\section{Synthesis of Schiff bases (SB1-13)}

Various Schiff bases were synthesized by the condensation of a mixture of 2-amino- 6-methyl benzothiazole $(0.01$ mole) with various substituted aromatic aldehydes ( 0.01 mole) was refluxed in absolute ethanol in presence of glacial acetic acid for 6-8 $\mathrm{h}$ which

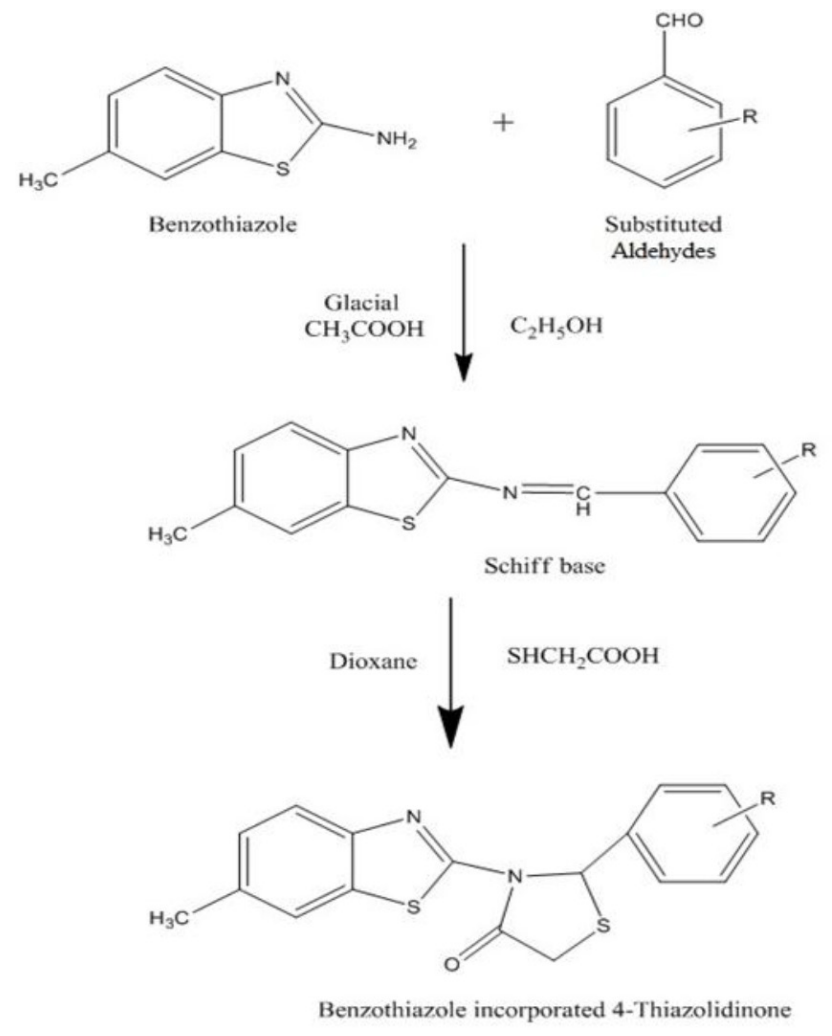

Figure 1: Scheme for the synthesis of benzothiazole substituted 4-thiazolidinone.

was precipitated with crushed ice and recrystallized from ethanol. ${ }^{9}$

Synthesis of Benzothiazole substituted 4-Thiazolidinones (TZ1-13)

Benzothiazole substituted 4-thiazolidinones derivatives were synthesized by cyclization of mixture of schiff bases (SB1-6) (0.01 mole) and thioglycolic acid (0.012mole) in 1,4- dioxane containing a pinch of anhydrous $\mathrm{ZnCl}_{2}$, which was refluxed for 8-10 h. The reaction mixture was then cooled and poured into crushed ice. The resulting solid was recrystallized from ethanol ${ }^{10}$ (Figure 1).

Physicochemical data of the synthesized compounds are given in the Table 1.

2-(2,3-dimethoxyphenyl)-3-(6-methylbenzo[d] thiazol-2-yl)thiazolidin-4-one (TZ1)

IR (KBr, $\mathbf{c m}^{-1)}$ : 2917(C-H), $1699(\mathrm{C}=\mathrm{O}), 1509(\mathrm{C}=\mathrm{N})$, 1478 $(\mathrm{C}=\mathrm{C}), \quad 1217(\mathrm{C}-\mathrm{N}), \quad 1366\left(-\mathrm{CH}_{3}\right), \quad 757(\mathrm{C}-\mathrm{S}-\mathrm{C})$, 2366 $\left(\mathrm{OCH}_{3}\right) . \quad{ }^{1} \mathbf{H} \quad$ NMR (300 MHz,DMSO-d $)$ : $2.341\left(\mathrm{~s}, \mathrm{CH}_{3}, 3 \mathrm{H}\right), 5.883(\mathrm{~s}, \mathrm{CH}$ of thiazolidinone, $1 \mathrm{H})$, 7.015-8.29(m,Ar-H,6H),3.606(s, $\mathrm{SCH}_{2}$ COof thiazolidinone, $2 \mathrm{H}), 3.87\left(\mathrm{~s},\left(\mathrm{OCH}_{3}\right)_{2}, 6 \mathrm{H}\right)$. MASS(LCMS), $\mathbf{m} / \mathbf{z} \cdot 386\left(\mathrm{M}^{+}\right)$.

2-(2-hydroxyphenyl)-3-(6-methylbenzo[d] thiazol2-yl)thiazolidin-4-one (TZ2)

IR (KBr, cm ${ }^{-1)}$ : 3649(O-H), $1642(\mathrm{C}=\mathrm{O}), 1523(\mathrm{C}=\mathrm{N})$, $1469(\mathrm{C}=\mathrm{C}), 1231(\mathrm{C}-\mathrm{N}), 1343\left(-\mathrm{CH}_{3}\right), 752(\mathrm{C}-\mathrm{S}-\mathrm{C}), 2897(\mathrm{C}-\mathrm{H})$. 


\begin{tabular}{|c|c|c|c|c|c|c|}
\hline $\begin{array}{l}\text { Compound } \\
\text { code }\end{array}$ & $\mathbf{R}$ & Molecular formula & Molecular weight & Physical state & Melting point ${ }^{\circ} \mathrm{C}$ & $\%$ yield \\
\hline TZ1 & $2,3-\mathrm{OCH}_{3}$ & $\mathrm{C}_{19} \mathrm{H}_{18} \mathrm{~N}_{2} \mathrm{O}_{3} \mathrm{~S}_{2}$ & 386.49 & Yellow crystal & $206-210$ & 74 \\
\hline TZ2 & $2-\mathrm{OH}$ & $\mathrm{C}_{17} \mathrm{H}_{14} \mathrm{~N}_{2} \mathrm{O}_{2} \mathrm{~S}_{2}$ & 342.44 & white crystal & 153-154 & 70 \\
\hline TZ3 & $4-\mathrm{NO}_{2}$ & $\mathrm{C}_{17} \mathrm{H}_{13} \mathrm{~N}_{3} \mathrm{O}_{3} \mathrm{~S}_{2}$ & 371.44 & Yellow crystal & $108-112$ & 49 \\
\hline TZ4 & $4-F$ & $\mathrm{C}_{17} \mathrm{H}_{13} \mathrm{~F} \mathrm{~N}_{2} \mathrm{OS}_{2}$ & 344.05 & White crystal & $148-151$ & 68 \\
\hline TZ5 & $2-\mathrm{Cl}$ & $\mathrm{C}_{17} \mathrm{H}_{13} \mathrm{CIN}_{2} \mathrm{OS}_{2}$ & 360.02 & White crystal & $121-122$ & 54 \\
\hline TZ6 & $2,5-\mathrm{OCH}_{3}$ & $\mathrm{C}_{19} \mathrm{H}_{18} \mathrm{~N}_{2} \mathrm{O}_{3} \mathrm{~S}_{2}$ & 386.49 & Brown crystal & $202-203$ & 68 \\
\hline TZ7 & $4-\mathrm{Br}$ & $\mathrm{C}_{17} \mathrm{H}_{13} \mathrm{Br} \mathrm{N}_{2} \mathrm{OS}_{2}$ & 404.34 & White crystal & $198-202$ & 72 \\
\hline TZ8 & $3-\mathrm{OH}$ & $\mathrm{C}_{17} \mathrm{H}_{14} \mathrm{~N}_{2} \mathrm{O}_{2} \mathrm{~S}_{2}$ & 342.44 & White crystal & $150-153$ & 64 \\
\hline TZ9 & $4-\mathrm{Cl}$ & $\mathrm{C}_{17} \mathrm{H}_{13} \mathrm{CIN}_{2} \mathrm{OS}_{2}$ & 360.02 & White crystal & $116-120$ & 69 \\
\hline TZ10 & $2-\mathrm{NO}_{2}$ & $\mathrm{C}_{17} \mathrm{H}_{13} \mathrm{~N}_{3} \mathrm{O}_{3} \mathrm{~S}_{2}$ & 371.43 & Yellow crystal & 153-155 & 54 \\
\hline TZ11 & $4-\mathrm{OCH}_{3}$ & $\mathrm{C}_{18} \mathrm{H}_{16} \mathrm{~N}_{2} \mathrm{O}_{2} \mathrm{~S}_{2}$ & 356.46 & White crystal & $135-136$ & 73 \\
\hline TZ12 & $3-\mathrm{NO}_{2}$ & $\mathrm{C}_{17} \mathrm{H}_{13} \mathrm{~N}_{3} \mathrm{O}_{3} \mathrm{~S}_{2}$ & 371.43 & yellow crystal & $152-153$ & 52 \\
\hline TZ13 & & $\mathrm{C}_{21} \mathrm{H}_{16} \mathrm{~N}_{2} \mathrm{OS}_{2}$ & 376.49 & Brownish crystal & $230-232$ & 54 \\
\hline
\end{tabular}

${ }^{1}$ H NMR (300 MHz,DMSO-d $)$ : 2.363(s, $\left.\mathrm{CH}_{3}, 3 \mathrm{H}\right)$, $5.183(\mathrm{~s}, \mathrm{CH}$ of thiazolidinone,1H), $7.125-8.16(\mathrm{~m}, \mathrm{Ar}-\mathrm{H}$, $7 \mathrm{H}), \quad 3.62\left(\mathrm{~s}, \quad \mathrm{SCH}_{2} \mathrm{CO}\right.$ of thiazolidinone, $\left.2 \mathrm{H}\right)$, 6.21(s,OH,1H). MASS(LCMS), $m / z: 342\left(\mathrm{M}^{+}\right)$.

3-(6-methylbenzo[d] thiazol-2-yl)-2-(4-nitrophenyl) thiazolidin-4-one (TZ3)

IR (KBr, $\mathbf{c m}^{-1)}$ : 3570(O-H), 1628(C=O), 1531(C=N), $1459(\mathrm{C}=\mathrm{C}), \quad 1229(\mathrm{C}-\mathrm{N}), \quad 1293\left(-\mathrm{CH}_{3}\right), \quad 749(\mathrm{C}-\mathrm{S}-\mathrm{C})$, 2884(C-H), 1535 and $1340\left(\mathrm{NO}_{2}\right) \cdot{ }^{1} \mathbf{H}$ NMR (300 MHz,DMSO-d $)$ : $2.312\left(\mathrm{~s}, \mathrm{CH}_{3}, 3 \mathrm{H}\right), 5.427(\mathrm{~s}, \mathrm{CH}$ of thiazolidinone, $1 \mathrm{H}), \quad 7.217-8.38 \quad(\mathrm{~m}, \mathrm{Ar}-\mathrm{H}, 7 \mathrm{H}), \quad 3.68$ (s, $\mathrm{SCH}_{2} \mathrm{CO}$ of thiazolidinone,2H). MASS(LCMS), $\mathrm{m} / \mathrm{z}: 371\left(\mathrm{M}^{+}\right)$.

2-(4-fluorophenyl)-3-(6-methylbenzo[d] thiazol2-yl)thiazolidin-4-one (TZ4)

IR (KBr, $\mathbf{c m}^{-1)}: 3190(\mathrm{C}-\mathrm{H}), 1683(\mathrm{C}=\mathrm{O}), 1558(\mathrm{C}=\mathrm{N})$, 1473 $(\mathrm{C}=\mathrm{C}), \quad 1279(\mathrm{C}-\mathrm{N}), \quad 1379\left(-\mathrm{CH}_{3}\right), \quad 782(\mathrm{C}-\mathrm{S}-$ C), 1207(C-F). ${ }^{1} \mathbf{H}$ NMR (300 MHz, DMSO-d $)$ : $2.345\left(\mathrm{~s}, \mathrm{CH}_{3}, 3 \mathrm{H}\right), 5.029(\mathrm{~s}, \mathrm{CH}$ of thiazolidinone, $2 \mathrm{H})$, $7.015-8.29$ (m, Ar- $\mathrm{H}, 7 \mathrm{H}), 3.606\left(\mathrm{~s}, \mathrm{SCH}_{2} \mathrm{CO}\right.$ of thiazolidinone, $1 \mathrm{H})$. MASS(LCMS), m/z: 344(M $\left.\mathrm{M}^{+}\right)$.

2-(2-chlorophenyl)-3-(6-methylbenzo[d] thiazol2-yl)thiazolidin-4-one (TZ5)

IR $\left(\mathbf{K B r}, \mathbf{c m}^{-1)}\right.$ : $3280(\mathrm{C}-\mathrm{H}), 1622(\mathrm{C}=\mathrm{O}), 1526(\mathrm{C}=\mathrm{N})$, 1475(C=C), 1225(C-N), 1385(-CH $)$, 785(C-S-C), 693(CCl). ${ }^{1} \mathbf{H}$ NMR (300 MHz, DMSO-d $)$ ): 2.361(s, $\mathrm{CH}_{3}$, $3 \mathrm{H}), 5.319(\mathrm{~s}, \mathrm{CH}$ of thiazolidinone,2H), $7.125-8.119$ (m, Ar-H, 7H), 3.647(s, $\mathrm{SCH}_{2} \mathrm{CO}$ of thiazolidinone, $1 \mathrm{H})$.

2-(2,5-dimethoxyphenyl)-3-(6-methylbenzo[d] thiazol-2-yl)thiazolidin-4-one (TZ6)

IR (KBr, $\mathbf{c m}^{-1)}:$ 3192(C-H),1638(C=O), 1561 (C=N), $1472(\mathrm{C}=\mathrm{C}), \quad 1212(\mathrm{C}-\mathrm{N}), \quad 1357\left(-\mathrm{CH}_{3}\right), \quad 784(\mathrm{C}-\mathrm{S}-\mathrm{C})$, 2348 $\left(-\mathrm{OCH}_{3}\right),{ }^{1} \mathbf{H}$ NMR (300 MHz, DMSO-d $)$ : 2.324(s, $\left.\mathrm{CH}_{3}, 3 \mathrm{H}\right), 5.489$ (s, $\mathrm{CH}$ of thiazolidinone, $2 \mathrm{H}$ ), $7.241-8.23(\mathrm{~m}, \mathrm{Ar}-\mathrm{H}, \quad 6 \mathrm{H}), \quad 3.74\left(\mathrm{~s}, \quad \mathrm{SCH}_{2} \mathrm{CO}\right.$ of thiazolidinone, $1 \mathrm{H}), 3.84\left(\mathrm{~s},\left(\mathrm{OCH}_{3}\right)_{2}, 6 \mathrm{H}\right)$.

2-(4-bromophenyl)-3-(6-methylbenzo[d] thiazol2-yl)thiazolidin-4-one (TZ7)

IR (KBr, $\left.\mathbf{c m}^{-1}\right): 3280(\mathrm{C}-\mathrm{H}), 1684(\mathrm{C}=\mathrm{O}), 1574(\mathrm{C}=\mathrm{N})$, 1509(C=C), 1281(C-N), 677(C-Br), 782(C-S-C), 1378($\mathrm{CH} 3)$.

${ }^{1} \mathbf{H}$ NMR (300 MHz, DMSO-d $)$ : 2.408(s, $\left.\mathrm{CH}_{3}, 3 \mathrm{H}\right)$, 5.293 (s, $\mathrm{CH}$ of thiazolidinone, $2 \mathrm{H}), \quad 7.241-8.23$ (m,Ar-H, 6H), 3.69(s, $\mathrm{SCH}_{2} \mathrm{CO}$ of thiazolidinone, $1 \mathrm{H}$ ), $3.84\left(\mathrm{~s},\left(\mathrm{OCH}_{3}\right)_{2}, 6 \mathrm{H}\right)$.

2-(3-hydroxyphenyl)-3-(6-methylbenzo[d] thiazol2-yl)thiazolidin-4-one (TZ8)

IR $\left(\mathbf{K B r}, \mathbf{c m}^{-1}\right)$ : 3649 $(-\mathrm{OH}), 1634(\mathrm{C}=\mathrm{O}), 1531(\mathrm{C}=\mathrm{N})$, 1473(C=C), $1349(\mathrm{C}-\mathrm{N}), \quad 781(\mathrm{C}-\mathrm{S}-\mathrm{C}), \quad 1373\left(-\mathrm{CH}_{3}\right)$. ${ }^{1} \mathbf{H}$ NMR(300 MHz,DMSO-d $)$ : 2.231(s, $\left.\mathrm{CH}_{3}, 3 \mathrm{H}\right)$, 5.191(s, CH of thiazolidinone,1H), $7.24-8.23$ (m,Ar-H, $7 \mathrm{H}), 3.56\left(\mathrm{~s}, \mathrm{SCH}_{2} \mathrm{CO}\right.$ of thiazolidinone, $\left.2 \mathrm{H}\right), 6.74(\mathrm{~s}, \mathrm{OH}$, 1H). MASS(LCMS), m/z: 342(M+). 
2-(4-chlorophenyl)-3-(6-methylbenzo[d] thiazol2-yl)thiazolidin-4-one (TZ9)

IR (KBr, $\left.\mathbf{c m}^{-1}\right)$ : 3289(C-H), 1682(C=O), $1537(\mathrm{C}=\mathrm{N})$, 1461 (C=C), 1218(C-N), 1340(-CH $), 693(\mathrm{C}-\mathrm{Cl}), 772(\mathrm{C}-\mathrm{S}-\mathrm{C})$. ${ }^{1} \mathbf{H}$ NMR (300MHz, DMSO-d6): 2.265(s, $\left.\mathrm{CH}_{3}, 3 \mathrm{H}\right)$, $5.341(\mathrm{~s}, \mathrm{CH}$ of thiazolidinone, $1 \mathrm{H}), 3.334\left(\mathrm{~s}, \mathrm{SCH}_{2} \mathrm{CO}\right.$ of thiazolidinone,2H), $7.185-7.905$ (m, Ar-H 7H). MASS(LCMS):m/z: 360.9682( $\left.\mathrm{M}^{+}\right), 362.9673(\mathrm{M}+1)$, $363.9689(\mathrm{M}+2)$.

3-(6-methylbenzo[d] thiazol-2-yl)-2-(2-nitrophenyl) thiazolidin-4-one (TZ10)

IR (KBr, $\left.\mathbf{c m}^{-1}\right)$ : $3736(\mathrm{C}-\mathrm{H}), 1704(\mathrm{C}=\mathrm{O}), 1522(\mathrm{C}=\mathrm{N})$, $1401(\mathrm{C}=\mathrm{C}), 1246(\mathrm{C}-\mathrm{N}), 1578$ and $1338\left(-\mathrm{NO}_{2}\right), 1313\left(-\mathrm{CH}_{3}\right)$, 807(C-S-C). ${ }^{1}$ H NMR (300 MHz,DMSO-d6): 2.279(s, $\left.\mathrm{CH}_{3}, 3 \mathrm{H}\right), \quad 5.453(\mathrm{~s}, \quad \mathrm{CH}$ of thiazolidinone, $1 \mathrm{H})$, 3.641(s, $\mathrm{SCH}_{2} \mathrm{CO}$ of thiazolidinone, $2 \mathrm{H}$ ), $7.20-8.025$ (m, Ar-H 7H).

2-(4-methoxyphenyl)-3-(6-methylbenzo[d] thiazol2-yl)thiazolidin-4-one (TZ11)

IR (KBr, $\left.\mathbf{c m}^{-1}\right)$ : 3193(C-H), $1629(\mathrm{C}=\mathrm{O}), 1570(\mathrm{C}=\mathrm{N})$, 1475(C=C), 1223(C-N), 1384(- $\left.\mathrm{CH}_{3}\right), \quad$ 781(C-S-C), 2916 $\left(\mathrm{OCH}_{3}\right)$. ${ }^{1} \mathbf{H}$ NMR (300 MHz,DMSO-d6): $2.423\left(\mathrm{~s}, \mathrm{CH}_{3}, 3 \mathrm{H}\right), \quad 5.731(\mathrm{~s}, \mathrm{CH}$ of thiazolidinone, $1 \mathrm{H})$, $3.497\left(\mathrm{~s}, \mathrm{SCH}_{2} \mathrm{CO}\right.$ of thiazolidinone,2H), $7.24-8.28$ (m, Ar-H 7H). MASS(LCMS):m/z: $356.07\left(\mathrm{M}^{+}\right)$

3-(6-methylbenzo[d] thiazol-2-yl)-2-(3-nitrophenyl) thiazolidin-4-one (TZ12)

IR (KBr, $\left.\mathbf{c m}^{-1}\right): 2955(\mathrm{C}-\mathrm{H}), 1685(\mathrm{C}=\mathrm{O}), 1504(\mathrm{C}=\mathrm{N})$, 1457(C=C), 1572 and $1389\left(\mathrm{NO}_{2}\right), 1160(\mathrm{C}-\mathrm{N}), 1317\left(-\mathrm{CH}_{3}\right)$, 732(C-S-C). $\quad{ }^{1} \mathbf{H} \quad$ NMR (300 MHz,DMSO-d6): $2.466\left(\mathrm{~s}, \mathrm{CH}_{3}, 3 \mathrm{H}\right), 5.19$ (s, $\mathrm{CH}$ of thiazolidinones, $\left.1 \mathrm{H}\right)$, 3.812(s, $\mathrm{SCH}_{2} \mathrm{CO}$ of thiazolidinone, $\left.2 \mathrm{H}\right), 7.356-7.850$ (m,Ar-H, 7H). MASS(LCMS):m/z: 371( $\left.\mathrm{M}^{+}\right)$

3 - (6 - methylbenzo [d] thiazo1-2-y1) - 2 - (4(naphthalen-1-yl)phenyl)thiazolidin-4-one (TZ13)

IR (KBr, $\left.\mathbf{c m}^{-1}\right): 3287(\mathrm{C}-\mathrm{H}), 1687(\mathrm{C}=\mathrm{O}), 1597(\mathrm{C}=\mathrm{N})$, 1478(C=C), 1222(C-N), 1388(-CH3), 1108(C-O), 771(CS-C) ${ }^{1} \mathbf{H}$ NMR (300 MHz,DMSO-d6): 2.614 (s, $\left.\mathrm{CH}_{3}, 3 \mathrm{H}\right)$, 5.41 (s, $\mathrm{CH}$ of thiazolidinones, $1 \mathrm{H}), 3.782\left(\mathrm{~s}, \mathrm{SCH}_{2} \mathrm{CO}\right.$ of thiazolidinone, $2 \mathrm{H}), 7.294-8.872(\mathrm{~m}, \mathrm{Ar}-\mathrm{H}, 14 \mathrm{H})$.

\section{In silico studies}

In-silico studies were performed by determining ADMET properties, Lipinski's rule of five are mainly focused to determine drug likeness and suitable and preferred orientation of the molecule. ${ }^{11-13}$

\section{Drug likeness evaluation of benzothiazole substituted 4-thiazolidinones}

a. Determination of Lipinski's rule of Five and physico-chemical parameters of benzothiazole substituted 4-thiazolidinones:-

Lipinski's rule of 5 is mainly used to verify molecular properties which are essential and related to PK of the drug molecule using Mol inspiration software. ${ }^{14-16}$

b. Analysis of electronic parameters and ADME properties of the benzothiazole substituted 4-thiazoidinones compounds:-

It is mainly by using Qikprop of Schrodinger 2018-3 suite device Maestro 11.7.012. Oikprop is a rapid, precise, accessible to predict ADME properties. ${ }^{17,18}$

c. Evaluation of toxicity of the benzothiazole substituted 4-thiazolidinones

In many stages of drug development, assessment of safety and toxicity must be done. In many cases, toxic effects are identified in the later stage of the development. In the drug development prior precise assessments are very important. In silico toxicity determination is one of the way to avoid such incidents. Toxicity prediction was mainly done using admit SAR database which is freely available. ${ }^{19,20}$

\section{d. Molecular Docking Studies}

Molecular docking was performed by utilizing Glide module of Schrodinger 2018-3 suite device Maestro 11.7.012. Crystal structures with good resolution of all the target proteins were taken from PDB..$^{21-23}$

\section{In-vitro Anticancer Activity}

Analysis of cell viability is a valuable tool for cytotoxic study and short term cytotoxicity study by trypan blue dye exclusion assay. Cell membrane integrity has been ascertained as the basic factor for differentiating dead cells from live cells. Thus, using a neubauer chamber the relative number of live and dead cells are counted. ${ }^{24-26}$

The $\%$ growth inhibition is estimated by utilizing the following formula:

$\%$ growth inhibition $=100-\left(\frac{\text { total cells }- \text { dead cells }}{\text { total cells }}\right) \times 100$

In-vivo Anticancer activity of compound TZ4 against EAC induced peritoneal ascites in mice

The earlier approval from the IAEC was taken to carry out these studies (Proposal number: NGSMIPS/IAEC/ MARCH-2018/82). 
Acute toxicity studies: Performed as per OECD guidelines No 425.

In-vivo anticancer activity: The anticancer activity was assessed using EAC model in mice. 24 male mice were divided into 4 groups of 6 each. All the animals, except Group 1 were injected intra peritoneally with $1 \times 10^{6}$ EAC cells. Group-1 and Group-2 animals received vehicle $(0.5 \% \mathrm{w} / \mathrm{v} \mathrm{CMC}, 10 \mathrm{ml} / \mathrm{kg}$, p.o.) and served as a normal and disease control, respectively. Group 3 animals received, standard, 5-fluorouracil (10 $\mathrm{mg} / \mathrm{kg}$, i.p.). Group 4 and 5 animals received compound TZ14 at a dose of 5 and $10 \mathrm{mg} / \mathrm{kg}$, p.o., respectively. The treatment was started $24 \mathrm{~h}$ after tumor inoculation and continued for the duration of 10 days. During the study period all the animals were monitored for clinical signs and mortality. The body weights of all the animals were recorded once in every 3 days during the study period. ${ }^{27-29}$ The percentage increase in mean survival time (\%MST) was calculated using the following formula;

$$
\% \operatorname{MST}=(1-\mathrm{T} / \mathrm{C}) * 100
$$

$\mathrm{T}=$ Mean survival time of treated group; $\mathrm{C}=$ Mean survival time of control group.

\section{RESULTS AND DISCUSSION}

The synthesis of novel benzothiazole substituted 4-thiazolidinone derivatives were done by the condensation of a mixture of 2-amino-6-methyl benzothiazole with various substituted aromatic aldehydes, resultant Schiff bases were treated with thioglycolic acid in presence of pinch of anhydrous $\mathrm{ZnCl}_{2}$. Characterisation was done by physicochemical and spectral analysis.

In the IR spectrum of the all compounds clearly showed the absorption of the carbonyl group in the range of $1622-1699 \mathrm{~cm}^{-1}$ and absorption in the range of $749-785 \mathrm{~cm}^{-1}$ indicates the formation of C-S-C which represents the formation of thiazolidinone ring. The ${ }^{1} \mathrm{H}$ NMR spectra of all the compounds showed a sharp singlet at $\delta=5.029-5.883$ represents the $\mathrm{CH}$ group of thiazolidinone. Another sharp singlet observed at $\delta=3.606-3.74$ indicates the presence $-\mathrm{SCH}_{2} \mathrm{CO}$ functionality of thiazolidinone $(2 \mathrm{H})$. Appearance of multiples in the region of $\delta=7.015-8.29$ shows the presence of aromatic protons.

Based on the results of in-silico studies it was inferred that, Most of the compounds successfully satisfied all the parameters of Lipinski's rule of five without any violation except compounds TZ7, TZ13 (1 violation). All the compounds were found to have the molecular weight lesser than 500 Daltons. $\log P$ values of all the derivatives ranges from 3.79-5.95. So that all the compounds were expected to show good intestinal absorption. It was predicted that compound TZ8 will be hydrophilic since its $\log \mathrm{P}$ value is 3.79 whereas compound TZ13 will be most lipophilic as it has $\log$ $\mathrm{P}$ of 5.95. So permeability of this compound through cell membrane may be more. This is the point to consider and some structural alteration, modification can be carried out for remaining compounds to improve their permeability. Total number of hydrogen bond acceptors and donors are the good oral bioavailability predictors. Number of hydrogen bond acceptors and donors in all the screened compounds were within the permitted range i.e. not more than 10 and 5 respectively. tPSA is related to hydrogen bonding potential of compound and good descriptor to characterize Drug absorption, Bioavailability, Caco- 2 permeability and $\mathrm{BBB}$ penetration. For all the screened compounds tPSA is found to be in the range of $33.20-79.03$, this is much lower and within the permitted range i.e $140 \AA$ and which are comparable with standard 5-Flurouracil. Number of rotatable bonds measures molecular flexibility and a good descriptor of absorption and bioavailability of drugs. All the 13 compounds were found to have number of rotatable bonds lesser than 10. All of them found as flexible and they are comparable with standard Pazopanib. So all the screened compounds were found to have very good physicochemical properties and may have promising oral bioavailability (Table 2).

Screened compounds do not have any reactive functional groups, so there may not be any decomposition or toxicity problems in-vivo. Total solvent accessible surface area (SASA) in square angstroms (surface area of a bio molecule that is accessible to a solvent) calculated using a probe with a $1.4 \AA$ radius, SASA values for the compounds is found to be within the recommended range and are comparable with standard drug Pazopanib. Calculated Hydrophobic component of the SASA i.e saturated carbon and attached hydrogen for all the derivatives were found to fall between the accepted range and value of TZ11 is comparable with standard Pazopanib. Hydrophilic component of the SASA i.e SASA of N, O and $\mathrm{H}$ on hetero atoms for all the compounds were within the range and compounds TZ3, TZ8, TZ10, TZ12 were found to have their values which are nearer to standard drugs. Molar volume was calculated based on group contributors and it also analyses the transport characteristics of molecule mainly HIA or BBB. It was found that calculated values of molar volumes were within the range. Measure of total polarizability of molecule describing the steric 
Table 2: Lipinski's rule of five and physico chemical parameters of benzothiazole substituted 4-thiazolidinones.

\begin{tabular}{|c|c|c|c|c|c|c|c|}
\hline Compound & MW & Log P & nON & nOHNH & n voilation & tPSA & Nrotb \\
\hline TZ1 & 386.50 & 4.12 & 5 & 0 & 0 & 51.67 & 4 \\
\hline TZ2 & 342.44 & 4.24 & 4 & 1 & 0 & 53.43 & 2 \\
\hline TZ3 & 371.44 & 4.26 & 6 & 0 & 0 & 79.03 & 3 \\
\hline TZ4 & 344.44 & 4.46 & 3 & 0 & 0 & 33.20 & 2 \\
\hline TZ5 & 360.89 & 4.93 & 3 & 0 & 0 & 33.20 & 2 \\
\hline TZ6 & 386.50 & 4.34 & 5 & 0 & 0 & 51.67 & 4 \\
\hline TZ7 & 405.34 & 5.11 & 3 & 0 & 1 & 33.20 & 2 \\
\hline TZ8 & 342.44 & 3.79 & 4 & 1 & 0 & 53.43 & 2 \\
\hline TZ9 & 360.89 & 4.98 & 3 & 0 & 0 & 33.20 & 2 \\
\hline TZ10 & 371.44 & 4.21 & 6 & 0 & 0 & 79.03 & 3 \\
\hline TZ11 & 356.47 & 4.36 & 4 & 0 & 0 & 42.44 & 3 \\
\hline TZ12 & 371.44 & 4.23 & 6 & 0 & 0 & 79.03 & 3 \\
\hline TZ13 & 432.57 & 5.95 & 4 & 0 & 1 & 42.44 & 5 \\
\hline Pazopanib. & 437.53 & 3.27 & 9 & 3 & 0 & 119.04 & 5 \\
\hline $5-F U$ & 130.08 & -0.9 & 4 & 2 & 0 & 58.2 & 0 \\
\hline
\end{tabular}

effects and predicted polarizability of the compounds are within the range and values of TZ1, TZ13, TZ6 are comparable with standard drug Pazopanib.

Caco-2 cells are a model for the gut-blood barrier and predictions are for non-active transport. Predicted apparent Caco-2 cell permeability of compounds TZ3 and TZ12are 400.183 and 426.899 respectively. So they are expected to have satisfactory Caco-2 cell permeability. Values of compounds TZ8 and TZ10 are 927.48 and 569.289, so they may show good permeability where as all other compounds have greater values of permeability. So most of the compounds were expected to have good intestinal permeability. Predicted values for brain/blood partition coefficient for all the screened compounds fall into the recommended range. MDCK cells are considered to be a good mimic for the BBB. Most of the derivatives expected to show excellent MDCK cell permeability, whose values are much greater than the standard drug values. All the compounds were expected to have good BBB and skin permeability. Compounds TZ12 and TZ3 are showing nearer values to standard drug Pazopanib. Values for Prediction of binding to human serum albumin for all the compounds are within the recommended range. Values of TZ8, TZ5, TZ2, TZ4 are comparable with standard Pazopanib. In the determination of qualitative human oral absorption, Compound TZ13 is expected to have low human oral absorption. Remaining compounds are found to show high human oral absorption, these values are similar to the standard drug Pazopanib (Table 3).

Ames toxicity studies are mainly performed to determine whether "the compound is mutagenic or not". It is one of the extensively used method that employ bacteria to analyse whether a particular chemical is able to produce mutations in the DNA of that bacteria. Out of all the screened compounds TZ3, TZ1O and TZ12 are found as Ames toxic, with similar probability of $87 \%$. Remaining compounds are Non Ames toxic, in which TZ5 has higher probability. All the compounds were found to fall in category III of Acute oral toxicity which means all the compounds may have good $\mathrm{LD}_{50}$ values i.e 500mg and 5000mg. Compound TZ5 has highest probability of $75 \%$ which is higher than the standard drugs. Rat and fish toxicity values are comparable with standard drugs values. (Table 4)

Docking studies were performed by taking two different proteins which belonging to VEGFR2 family PDB ID: 2QU5 and 5HS3. VEGFR-2 plays important role as signal transducer mainly for angiogenesis. So, antiangiogenic therapy for cancer mainly focused and targeted on these receptors. Benzothiazole substituted 4-thiazolidinone derivatives were investigated whether these derivatives binding mode is correlated to VEGFR-2 inhibitors or not, by docking against VEGFR-2. For this Pazopanib which is a VEGFR2 inhibitor and 5-FU is a well-known anticancer agent are used as standards. Docking was performed in the groove of binding site present in 2QU5 and 5HS3. The binding affinity of these derivatives were expressed in terms of $G$ score as shown in the Table 6. All the derivatives were found to have binding free energy in the range of -6.84 to -4.83 and -5.88 to -4.52 for $2 \mathrm{QU} 5$ and 5HS3 respectively. Out of all 13 compounds, Compound TZ13 and TZ8 are having finest binding 


\begin{tabular}{|c|c|c|c|c|c|c|}
\hline \multicolumn{7}{|c|}{ Table 3: Electronic parameters of benzothiazole substituted 4-thiazolidinones. } \\
\hline Compound & \#rtvFG & $\begin{array}{c}\text { SASA } \\
\text { (square } \\
\text { angstroms) }\end{array}$ & FOSA & FISA & $\begin{array}{c}\text { Volume } \\
\text { (cubic } \\
\text { angstroms) }\end{array}$ & $\begin{array}{c}\text { QPpolrz } \\
\text { (cubic } \\
\text { angstroms) }\end{array}$ \\
\hline TZ1 & 0 & 638.66 & 306.62 & 50.27 & 1143.75 & 40.40 \\
\hline TZ2 & 0 & 580.78 & 144.28 & 93.52 & 1014.19 & 36.41 \\
\hline TZ3 & 0 & 613.09 & 146.36 & 146.69 & 1073.08 & 38.47 \\
\hline TZ4 & 0 & 578.51 & 146.65 & 53.46 & 1011.36 & 36.81 \\
\hline TZ5 & 0 & 589.37 & 143.24 & 53.77 & 1032.58 & 37.76 \\
\hline TZ6 & 0 & 642.29 & 333.87 & 50.95 & 1150.59 & 40.62 \\
\hline TZ7 & 0 & 605.39 & 147.7 & 49.41 & 1053.01 & 38.42 \\
\hline TZ8 & 0 & 582.33 & 145.83 & 108.46 & 1018.21 & 36.40 \\
\hline TZ9 & 0 & 600.44 & 147.66 & 49.47 & 1044.18 & 38.07 \\
\hline TZ10 & 0 & 599.09 & 140.81 & 130.82 & 1060.03 & 38.18 \\
\hline TZ11 & 0 & 605.97 & 238.55 & 53.97 & 1036.20 & 38.31 \\
\hline TZ12 & 0 & 609.67 & 145.22 & 144.00 & 1072.40 & 38.47 \\
\hline TZ13 & 0 & 749.97 & 177.1 & 54.97 & 1330.92 & 49.45 \\
\hline Pazopanib. & 0 & 709.00 & 281.03 & 193.71 & 1299.29 & 44.21 \\
\hline $5-F U$ & 0 & 262.27 & 0 & 163.17 & 385.69 & 9.79 \\
\hline
\end{tabular}

\begin{tabular}{|c|c|c|c|c|c|c|}
\hline \multicolumn{7}{|c|}{ Table 4: ADME properties of benzothiazole substituted 4-thiazolidinones. } \\
\hline Compound & $\begin{array}{c}\text { QPPCaco } \\
(\mathbf{n m} / \mathbf{s e c})\end{array}$ & QPlogBB & QPPMDCK & QPIogKp & $\begin{array}{c}\text { QPIogKhsa } \\
\text { Human Oral } \\
\text { Absorption }\end{array}$ \\
\hline TZ1 & 3305.003 & 0.115 & 4103.77 & -1.491 & 0.115 & 3 \\
\hline TZ2 & 1285.279 & -0.212 & 1529.59 & -2.178 & 0.226 & 3 \\
\hline TZ3 & 400.183 & -0.742 & 482.43 & -3.275 & 0.086 & 3 \\
\hline TZ4 & 3082.142 & 0.35 & 7362.77 & -1.586 & 0.216 & 3 \\
\hline TZ5 & 3061.672 & 0.348 & 7556.83 & -1.552 & 0.278 & 3 \\
\hline TZ6 & 3255.915 & 0.108 & 4072.27 & -1.522 & 0.135 & 3 \\
\hline TZ7 & 3367.348 & 0.458 & 10000 & -1.533 & 0.337 & 3 \\
\hline TZ8 & 927.48 & -0.346 & 1118.01 & -2.517 & 0.237 & 3 \\
\hline TZ9 & 3363.268 & 0.446 & 10000 & -1.531 & 0.312 & 3 \\
\hline TZ10 & 569.289 & -0.588 & 573.904 & -2.893 & 0.048 & 3 \\
\hline TZ11 & 3048.538 & 0.159 & 4011.40 & -1.562 & 0.141 & 3 \\
\hline TZ12 & 426.899 & -0.704 & 504.21 & -3.211 & 0.084 & 3 \\
\hline TZ13 & 2982.302 & -0.045 & 3950.10 & -0.671 & 0.816 & 3 \\
\hline Pazopanib. & 144.194 & -1.752 & 62.23 & -3.694 & 0.208 & 3 \\
\hline $5-$ FU & 280.853 & -0.465 & 222.16 & -4.338 & -0.749 & 3 \\
\hline
\end{tabular}

energies with binding score of -6.84 and -5.82 and highest binding affinity towards 2QU5 (Figure 2 and Figure 3) and Compound TZ1,TZ4, TZ8 are having binding score of $5.85,-5.75$ and 5.88 for 5 HS3 (Figure 4-6) were also found to have better binding affinity. Docking of the standard drugs revealed that Pazopanib has highest binding affinity towards both 2QU5 and 5HS3 with binding free energies of -8.32 and -7.137 respectively. In compound TZ8 interaction with 2QU5, Hydrogen bonding interactions of keto
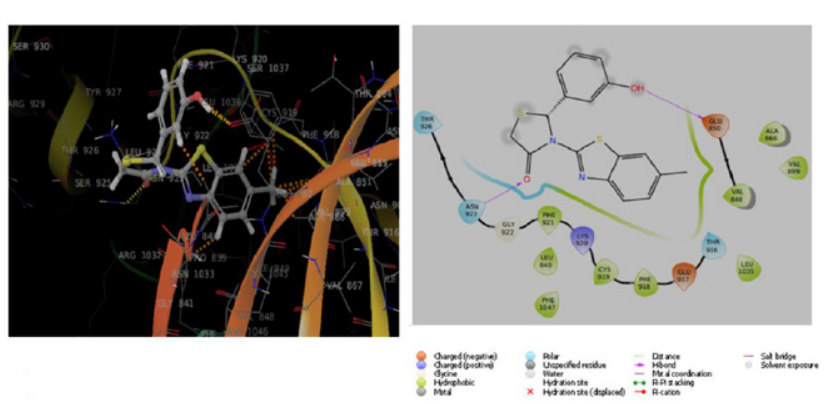

Figure 2: Interaction of TZ8 with 2 QU5. 

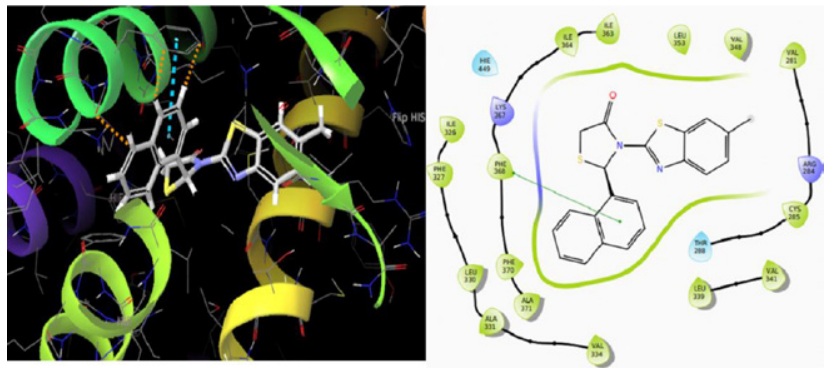

Figure 3: Interaction of TZ13 with 2 QU5.

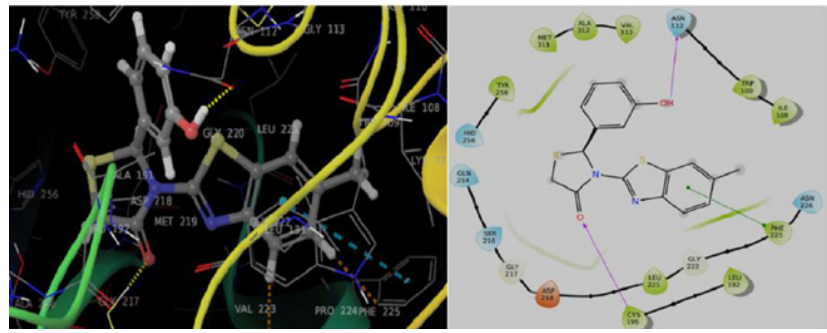

Figure 4: Interaction of TZ8 with 5 HS3.
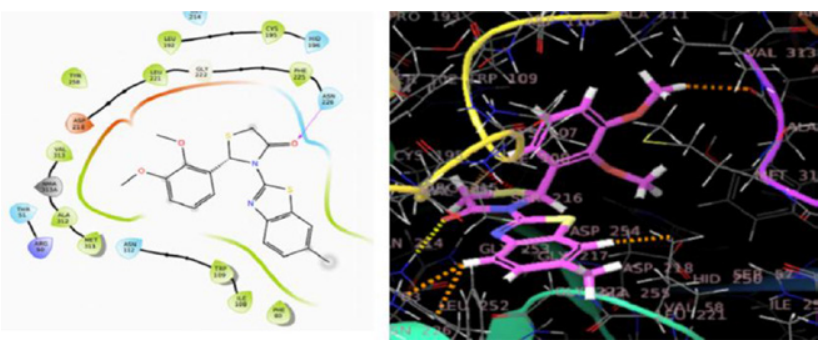

Figure 5: Interaction of TZ1 with 5HS3. group of thiazolidinone ring and hydroxyl substitution on the phenyl ring with ASN 923 and GLU 850 respectively. Methyl substituted benzothiazole ring was found to bind in the hydrophobic pocket formed by the PHE 921, CYS 919, PHE 918, VAL 848. In TZ13 interaction with 2QU5, Pi-Pi stacking can be seen between Naphthalene moiety PHE 368. Naphthalene ring was found in the hydrophobic pocket formed by PHE 368, PHE 370, ALA 371. In the interaction of TZ8 with 5HS3 there are 2 Hydrogen bonding can be see with hydroxyl substitution of phenyl ring and keto group of 4-thiazolidinone ring with ASN 112 AND CYS 195 respectively. Pi-Pi stacking was seen in between the benzene ring of benzothiazole and PHE 225. In the interaction of TZ1 with 5HS3 hydrogen boding was seen between the keto group of 4-thiazolidinone ring and ASN 226. Methyl substituted benzothiazole was found in hydrophobic pocket formed by the TRP 109, ILE 108, PHE 80. Interaction of TZ4 with 5HS3, hydrogen boding was seen between the ketone group of the 4-thiazolidinone ring and ASN 226. Pi-Pi stacking was seen in between the benzene ring substituted with fluorine and PHE 225. From the result of the docking study, it was proposed that all the derivatives of benzothiazole substituted 4 thiazolidinones have binding affinity to VEGFR2. Out of all the predicted compounds TZ1, TZ4, TZ8 and TZ13 which were comparatively found to have highest docking scores. So, it was expected that these compounds will have good

\begin{tabular}{|c|c|c|c|c|c|c|c|c|}
\hline \multirow[t]{2}{*}{ Comp. code } & \multicolumn{2}{|c|}{ AMES toxicity } & \multicolumn{2}{|c|}{ Carcinogenicity } & \multicolumn{2}{|c|}{ Acute Oral Toxicity } & \multirow{2}{*}{$\begin{array}{l}\text { Rat acute toxicity } \\
L_{5} \mathrm{D}_{50} \mathrm{~mol} / \mathrm{kg}\end{array}$} & \multirow{2}{*}{$\begin{array}{l}\text { Fish toxicity } \\
\mathrm{pLC}_{50} \mathrm{mg} / \mathrm{L}\end{array}$} \\
\hline & Result & Probability & Result & Probability & Result & Probability & & \\
\hline $\mathrm{TZ1}$ & - & 0.5719 & - & 0.8563 & III & 0.6783 & 2.1905 & 0.9789 \\
\hline TZ2 & - & 0.6500 & - & 0.8545 & III & 0.6275 & 2.2319 & 1.1585 \\
\hline TZ3 & + & 0.8738 & - & 0.7438 & III & 0.6695 & 2.4358 & 1.3387 \\
\hline TZ4 & - & 0.6571 & - & 0.8583 & III & 0.6857 & 2.3415 & 1.2360 \\
\hline TZ5 & - & 0.6441 & - & 0.8475 & III & 0.6993 & 2.4165 & 1.2123 \\
\hline TZ6 & - & 0.6720 & - & 0.8451 & III & 0.7486 & 2.3121 & 1.1355 \\
\hline TZ7 & - & 0.6054 & - & 0.8491 & III & 0.6672 & 2.1690 & 0.9263 \\
\hline TZ8 & - & 0.6407 & - & 0.8395 & III & 0.6462 & 2.1719 & 1.2349 \\
\hline TZ9 & - & 0.6619 & - & 0.8312 & III & 0.7223 & 2.2787 & 1.7819 \\
\hline TZ10 & + & 0.8746 & - & 0.7678 & III & 0.6644 & 2.4034 & 1.4349 \\
\hline TZ11 & - & 0.5978 & - & 0.8758 & III & 0.6605 & 2.0258 & 1.0634 \\
\hline TZ12 & + & 0.8738 & - & 0.7438 & III & 0.6695 & 2.4358 & 1.3387 \\
\hline TZ13 & - & 0.6603 & - & 0.8464 & III & 0.7221 & 2.0595 & 1.1009 \\
\hline Pazopanib. & - & 0.6543 & - & 0.8567 & III & 0.6642 & 2.3961 & 1.7277 \\
\hline 5-FU & - & 0.8941 & - & 0.9288 & III & 0.4387 & 2.2529 & 2.1015 \\
\hline
\end{tabular}




\begin{tabular}{|c|c|c|}
\hline \multirow[t]{2}{*}{ Compound } & \multicolumn{2}{|c|}{$\begin{array}{c}\text { G-Score/ Dock score } \\
\text { (kcal/mol) }\end{array}$} \\
\hline & 2QU5 & $5 \mathrm{HS} 3$ \\
\hline TZ1 & -5.33 & -5.85 \\
\hline TZ2 & -5.47 & -5.26 \\
\hline TZ3 & -5.32 & -5.38 \\
\hline TZ4 & -5.32 & -5.75 \\
\hline TZ5 & -5.42 & -5.48 \\
\hline TZ6 & -5.44 & -5.03 \\
\hline TZ7 & -5.22 & -5.51 \\
\hline TZ8 & -5.82 & -5.88 \\
\hline TZ9 & -5.32 & -5.66 \\
\hline TZ10 & -4.83 & -4.52 \\
\hline TZ11 & -5.33 & -5.71 \\
\hline TZ12 & -5.32 & -5.44 \\
\hline TZ13 & -6.84 & -4.57 \\
\hline Pazopanib & -8.32 & -7.137 \\
\hline 5 Fluro uracil & -5.75 & -4.549 \\
\hline
\end{tabular}

binding affinity and they were selected for further studies. (Table 5)

In-vitro cytotoxicity study of the synthesized compounds were determined by viability assay i.e trepan blue exclusion test which verifies the cytotoxic effect of the tested compounds. From the result it was clearly seen that in all four compounds were found to have cytotoxic activity and is increasing with increase in
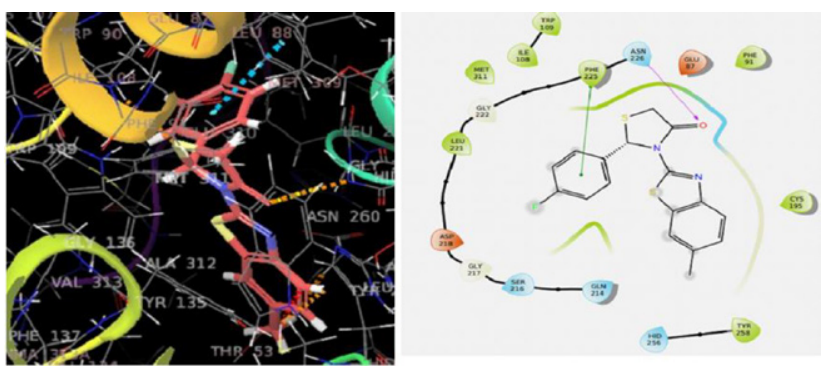

Figure 6: Interaction of TZ4 with 5HS3.

Cell Viability Test

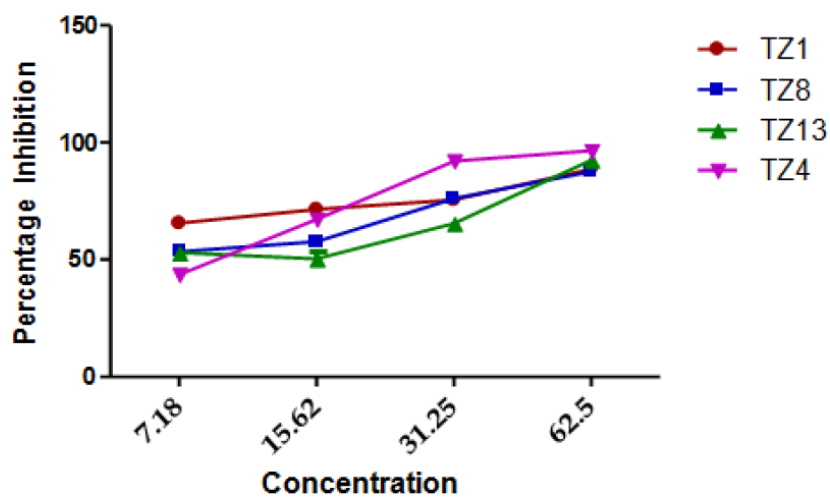

Figure 7: Mean percentage inhibition of TZ1,TZ8,TZ13,TZ4 in Trypan blue exclusion assay.

concentration, In other words, dose dependent cytotoxicity was seen with the tested compounds. Out of all the compounds TZ4 was found to have highest cytotoxicity where $41.38 \%-97.3 \%$ cell death was seen with different concentration of drug. CTC $_{50}$ was calculated which was found to be $15.93 \mu \mathrm{g} / \mathrm{ml}$. So

\begin{tabular}{|c|c|c|c|c|c|}
\hline & $\begin{array}{c}\text { G1 } \\
\text { Normal control }\end{array}$ & $\begin{array}{c}\text { G2 } \\
\text { Disease Control }\end{array}$ & G3 & G4 & G5 \\
\hline & $\begin{array}{c}\text { (Vehicle } 10 \mathrm{ml} / \mathrm{kg}, \\
\text { p.o.) }\end{array}$ & $\begin{array}{c}\text { (Vehicle } 10 \mathrm{ml} / \mathrm{kg} \text {, } \\
\text { p.o.) }\end{array}$ & $\begin{array}{c}5-\mathrm{FU} \\
(20 \mathrm{mg} / \mathrm{kg} \text {, i.p.) }\end{array}$ & $\begin{array}{c}\text { TZ4 } \\
\text { (5 mg/kg, p.o.) }\end{array}$ & $\begin{array}{c}\text { TZ4 } \\
(10 \mathrm{mg} / \mathrm{kg}, \text { p.o.) }\end{array}$ \\
\hline Day-0 & $28 \pm 1.5$ & $29.7 \pm 3.2^{\#}$ & $28.4 \pm 2.8$ & $29.2 \pm 1.7$ & $29 \pm 2.3$ \\
\hline Day-3 & $28.8 \pm 1.5$ & $32.3 \pm 3.1^{\#}$ & $29.3 \pm 2.7$ & $31.1 \pm 1.6$ & $30.9 \pm 2.1$ \\
\hline Day-6 & $29.6 \pm 1.4$ & $34.7 \pm 2.8^{\#}$ & $30.3 \pm 2.7^{*}$ & $33.2 \pm 1.7$ & $32.8 \pm 2$ \\
\hline Day-9 & $30.4 \pm 1.5$ & $36.9 \pm 2.9^{\#}$ & $31.5 \pm 2.7^{*}$ & $35.2 \pm 1.7$ & $34.9 \pm 1.9$ \\
\hline Day-12 & $31.2 \pm 1.5$ & $39.1 \pm 3.1^{\#}$ & $32.6 \pm 2.8^{*}$ & $37.2 \pm 1.7$ & $36.7 \pm 1.9$ \\
\hline Day-15 & $32 \pm 1.4$ & $41.5 \pm 3.3^{\#}$ & $33.8 \pm 2.8^{*}$ & $39.4 \pm 1.7$ & $38.7 \pm 2.1$ \\
\hline Day-18 & $32.7 \pm 1.5$ & $44.0 \pm 3.5^{\#}$ & $34.8 \pm 2.9^{*}$ & $41.2 \pm 1.8$ & $40.6 \pm 1.9$ \\
\hline Day-21 & $33.5 \pm 1.5$ & $46.5 \pm 3.6^{\#}$ & $35.7 \pm 3.2^{*}$ & $43.1 \pm 2.1$ & $42.6 \pm 1.6$ \\
\hline Day-23 & $34.3 \pm 1.5$ & $49.5 \pm 3.5^{\#}$ & $36.9 \pm 3.6^{*}$ & $45.1 \pm 1.9^{*}$ & $44.6 \pm 1.6^{*}$ \\
\hline Day-25 & $35.1 \pm 1.6$ & $53.9 \pm 1.7^{\#}$ & $38.0 \pm 3.6^{*}$ & $46.9 \pm 1.9^{*}$ & $46.6 \pm 1.6^{*}$ \\
\hline Day-27 & $35.4 \pm 1.7$ & $56.4 \pm 2.3^{\#}$ & $39.0 \pm 3.8^{*}$ & $49.0 \pm 2.0$ & $48.5 \pm 1.5^{*}$ \\
\hline Day-29 & $35.8 \pm 1.7$ & $58.9 \pm 2.2^{\#}$ & $40.1 \pm 3.8^{*}$ & $51.0 \pm 2.1^{*}$ & $50.5 \pm 1.6^{*}$ \\
\hline
\end{tabular}

$p<0.05$ when compared to $\mathrm{G}_{1}$ Normal;

*: $p<0.05$ when compared to G2, EAC control. 
TZ4 may considered to have better cytotoxic activity which was further confirmed by in-vivo studies. (Table 7) In-vivo anticancer activity of synthesized compounds were performed to determine effect on mortality and survival time of animal. The standard and test drugs treatment has shown a dose dependent protection against EAC induced mortality. The low and high dose of TZ4 increased the survival time by (\%ILS) 30.7 and $52.9 \%$, respectively. The mean survival time (MST) of low and high dose treated animals with TZ4 was found to be 37.3 and41.0 days respectively, when compared to control (MST-31.5 days). The above results are comparable with standard, 5-Fluorouracil (\%ILS-98.7\% and MST-55.2 days).

The EAC inoculated G2 (Disease control) showed a significant increase in body weight (Day-6 onwards) when compared to normal control, G1. The test drug treated groups showed a dose dependent reduction in body weight when compared to disease control, G2. The TZ4 low and high dose treated groups showed significant protection against EAC induced increase in body weight from day 23 of treatment $(p<0.05)$ and the aboveresultswere comparableto standard,5-Fluorouracil, treated group (G3). So, the tested compound, TZ4 shows a significant dose dependent anticancer activity against EAC induced peritoneal ascites in mice. The results are comparable to standard 5-Flurouracil. (Table 7)

\section{In-vivo Anticancer Studies}

The data were represented as \pm mean SD and analyzed by one-way ANOVA followed by Dennett's multiple comparison tests using Prism software (Version 4). P values $\leq 0.05$ were considered significant.

\section{CONCLUSION}

The main objective of this study was to synthesize the new benzothiazole substituted 4-thiazolidinone derivatives and screening their cytotoxic potency. The synthesis of novel benzothiazole substituted 4-thiazolidinone derivatives, characterization was done by physicochemical characteristics and spectral studies. In silico studies with molecular docking was performed to filter best compounds out of 13 different derivatives. Based on the docking score four molecules were selected for in vitro anticancer activity and tested compounds showed good dose dependent cytotoxic activity. Out of 4 compounds TZ4 was found to show better cytotoxic effect and which was further analyzed by in vivo anticancer activity and which enhances life span of EAC bearing mice with concentration of $10 \mathrm{mg} /$ kg. So we conclude that all the screened benzothiazole substituted 4-thiazolidinone derivatives are effective cytotoxic agents (Figure 7). Compound TZ4 was found as promising molecule may be because of presence of highly electro negative fluorine atom.

\section{ACKNOWLEDGEMENT}

The authors would like to thank NGSM Institute of Pharmaceutical Sciences and CADD Lab, NGSMIPS, NITTE (Deemed to be University) for providing the necessary facilities to conduct this research.

We would like to thank Dr. Praveen, JSS College of Pharmacy, Ooty for in vitro anticancer studies.

\section{CONFLICT OF INTEREST}

The authors declare no conflict of interest.

\section{ABBREVIATIONS}

VEGFR-2: Vascular Endothelial Growth Factor Receptor-2; EAC: Ehrlich Ascites Carcinoma; \%ILS: Percentage Increase in Life Span; MST: Mean Survival Time; $\mathbf{L D}_{50}$ : Lethal Dose 50; tPSA: Topological Polar Surface Area; BBB: Blood Brain Barrier; MDCK: Madin-Darby Canine Kidney cells;

\section{REFERENCES}

1. Nagy M. Khalifa, 1,2 Mohamed A. Al-Omar, 1,3 Hamad M. Alkahtani, 3 and Ahmed H. Bakheit. Kinase Inhibitors of Novel Pyridopyrimidinone Candidates: Synthesis and in vitro Anticancer Properties. 2019. https://doi. org/10.1155/2019/2635219. 1-10.

2. Abou-Ghadir OF, Alaa MH, Abdel-Moty SG, Mostafa AH, Ahmed SA, Douaa S. Design, Molecular Modeling and Synthesis of Some New Purine-diones and Pyridopyrimidine-diones with Anticancer Activity. Journal of Advances in chemistry. 2017;13(2):5959-76.

3. Gali K, Ramakrishnan G, Kothai R, Jaykar B. In-vitro anti-cancer activity of methanolic extract of leaves of Argemone mexicana Linn. Int J PharmTech Res. 2011;3:1329-33.

4. Jain AK, Vaidya A, Ravichandran V, Kashaw SK, Agrawal RK. Recent developments and biological activities of thiazolidinone derivatives: A review. Bioorganic and Medicinal Chemistry. 2012;20(11):3378-95.

5. Seetaramswamy S, Sekar V, Gandhimathi S, Murugesan L, Perumal P. Synthesis and in-vitro anticancer activity of some novel bis-benzothiazolederivatives. Int J Curr Pharm Res. 2013;5:63-4.

6. Kaminskyy D, Khyluk D, Vasylenko O, Zaprutko L, Lesyk R. A facile synthesis and anticancer activity evaluation of spiro [thiazolidinone-isatin] conjugates. Scientiapharmaceutica. 2011;79(4):763-78.

7. Lesyk RB, Zimenkovsky BS, Kaminskyy DV, Kryshchyshyn AP, Havryluk RB, Atamanyuk DV, et al. Thiazolidinone motif in anticancer drug discovery. Experience of DH LNMU medicinal chemistry scientific group. Biopolymers and Cell. 2011.

8. Gaware VM, Dhamak KB, Kotade KB. Synthesis and Evaluation of Benzothiazole Derivatives for Anthelmintic Activity. Euro J Pharm Med Res. 2016;3(5):454-9.

9. Havrylyuk D, Mosula L, Zimenkovsky B, Vasylenko O, Gzella A, Lesyk R. Synthesis and anticancer activity evaluation of 4-thiazolidinones containing benzothiazole moiety. European Journal of Medicinal Chemistry. 2010;45(11):5012-21. 
10. Nagararaju G, Sai KB, Chandana K, Guldipati M, Suresh PV, Ramarao N. Synthesis, evaluation of antioxidant and antimicrobial study of 2-substituted benzothiazole derivatives. Indo Am J Pharm Res. 2015;5:1288-96.

11. Muegge I. Selection criteria for drug-like compounds. Medicinal Research Reviews. 2003;23(3):302-21.

12. Khan SA, Kumar S, Maqsood AM. Virtual screening of molecular properties and bioactivity score of bowelled acid derivatives in search of potent antiinflammatory lead molecule. Intern J of Interdisciplinary and Multidisciplinary Studies. 2013;1(1):8-12.

13. Lipinski CA. Lead-and drug-like compounds: The rule-of-five revolution. Drug Discovery Today: Technologies. 2004;1(4):337-41.

14. Brito MA. Pharmacokinetic study with computational tools in the medicinal chemistry course. Brazilian Journal of Pharmaceutical Sciences. 2011;47(4):797-805.

15. Singh S, Gupta AK, Verma A. Molecular properties and bioactivity score of the Aloe vera antioxidant compounds-in order to lead finding. Research Journal of Pharmaceutical, Biological and Chemical Sciences. 2013;4(2):876-81.

16. Zhu K, Borrelli KW, Greenwood JR, Day T, Abel R, Farid RS, et al. Docking covalent inhibitors: A parameter free approach to pose prediction and scoring. Journal of Chemical Information and Modeling. 2014;54(7):1932-40.

17. Qidwai T. QSAR modelling, docking and ADMET studies for exploration of potential anti-malarial compounds against Plasmodium falciparum. In silico Pharmacology. 2017;5(1):6.

18. Guengerich FP. Mechanisms of drug toxicity and relevance to pharmaceutical development. Drug Metabolism and Pharmacokinetics. 2010;1010210090.

19. Cheng F, Li W, Zhou Y, Shen J, Wu Z, Liu G, et al. AdmetSAR: A comprehensive source and free tool for assessment of chemical ADMET properties. 2012.
20. Shibuya M. Vascular endothelial growth factor (VEGF) and its receptor (VEGFR) signaling in angiogenesis: A crucial target for anti-and pro-angiogenic therapies. Genes and Cancer. 2011;2(12):1097-105.

21. Ferreira LG, DosSantos RN, Oliva G, Andricopulo AD. Molecular docking and structure-based drug design strategies. Molecules. 2015;20(7):13384-421.

22. Brust R, Shang J, Fuhrmann J, Bass J, Cano A, Heidari Z, et al. A structural mechanism for directing inverse agonism of PPARy. Bio Rxiv. 2018;245852.

23. Banu BH, Rajitha G, Bharathi K. An Approach to Computer Aided Drug Design of some Bioactive Cinnamoyl Hydrazones, in silico and Docking Studies as Possible COX-2 Selective Inhibitors. J Biotechnol Biomater. 2016;6(3):1-8.

24. Neelamkavil SV, Thoppil JE. Evaluation of the anticancer potential of the traditional medicinal herb Isodoncoetsa. South Indian J Biol Sci. 2016;2(1):415.

25. Veni AK, Mohandass S. In-vitro Cytotoxic Activity of Enicostemmaaxillare Extract against Hela Cell Line. IJPPR. 2014;6(2):320-3.

26. Asirvatham R, Christina AJ, Murali A. In vitro antioxidant and anticancer activity studies on Droseraindica L.(Droseraceae). Advanced Pharmaceutical Bulletin. 2013;3(1):115-20.

27. Islam M, Rahi M, Jahangir CA, Rahman $\mathrm{MH}$, Jerin I, Amin $\mathrm{R}$, et al. In vivo Anticancer Activity of Basella alba Leaf and Seed Extracts against Ehrlich's Ascites Carcinoma (EAC) Cell Line. Evidence-Based Complementary and Alternative Medicine. 2018.

28. Manglani $\mathrm{N}$, Vaishnava $\mathrm{S}$, Dhamodaran $\mathrm{P}$, Sawarkar $\mathrm{H}$. In vitro and in vivo anticancer activity of leaf extract of Barleria grandiflora. Int. J. Pharm. Pharm. Res. 2014;6:70-2.

29. Kumar RS, Rajkapoor B, Perumal P. In vitro and in vivo anticancer activity of Indigofera cassioides Rottl. Ex. DC. Asian Pacific Journal of Tropical Medicine. 2011;4(5):379-85.
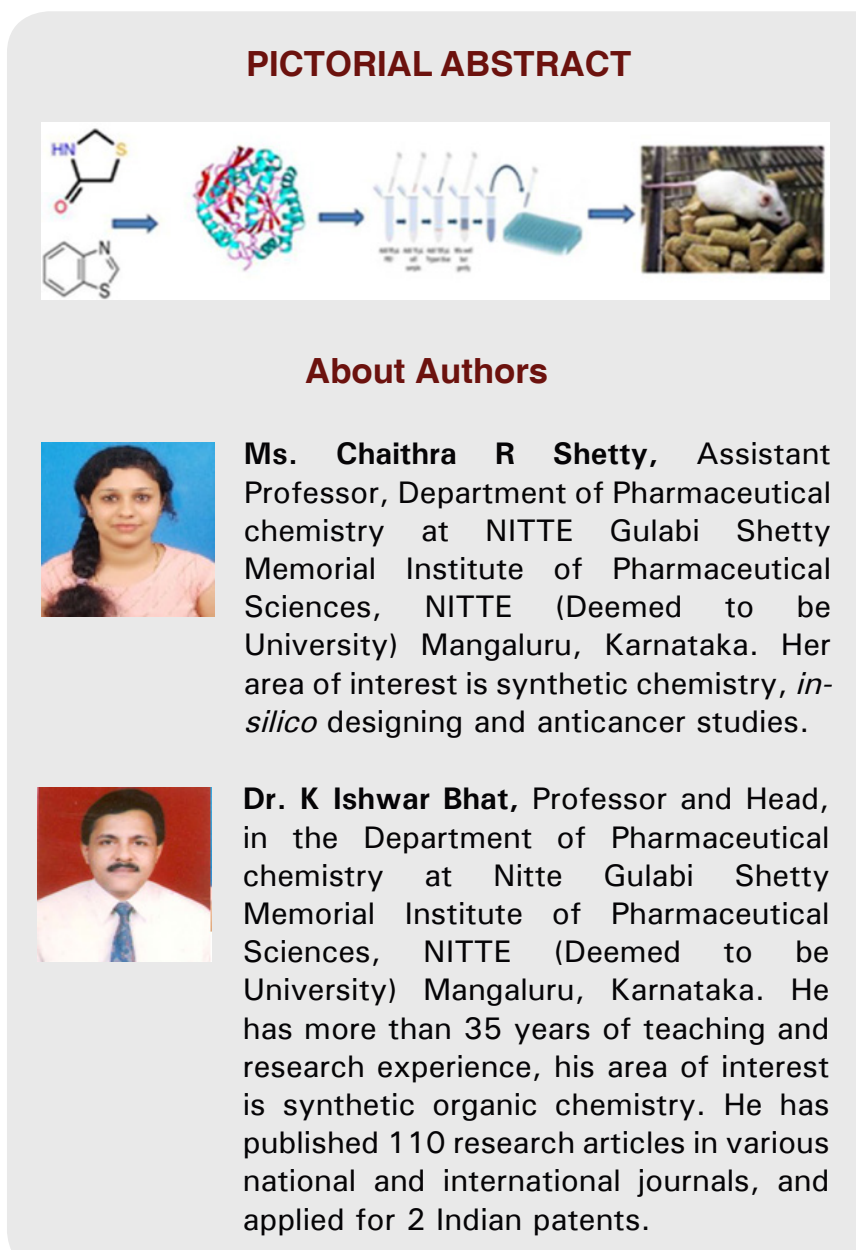

\section{SUMMARY}

Benzothiazole substituted 4-thiazolidinons were synthesized using 2-amino-6-methyl benzothiazole with various substituted aromatic aldehydes, resultant Schiff bases were treated with thioglycolic acid in presence of pinch of anhydrous $\mathrm{ZnCl}_{2}$. Based on the molecular docking compounds were selected for anticancer evaluation. In-vitro cytotoxicity study of the synthesized compounds were performed by trypan blue exclusion viability assay which verifies the cytotoxic effect of the tested compounds. Dose dependent cytotoxicity was seen with the tested compounds in in-vitro study. In-vivo anticancer activity of synthesized compounds were performed to determine effect on mortality and survival time of animal. The standard and test drugs treatment has shown a dose dependent protection against EAC induced mortality. So, the tested compound, TZ4 shows a significant dose dependent anticancer activity against EAC induced peritoneal ascites in mice. The results are comparable to standard 5-Flurouracil.

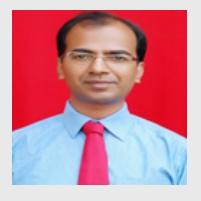

Dr. Abhishek Kumar is working as Assistant Professor, Department of Pharmaceutical Chemistry at NGSM Institute of Pharmaceutical Sciences, Mangaluru. His areas of interest are Synthetic Organic Chemistry, Insilico studies and spectral analysis of synthesized organic compounds. 


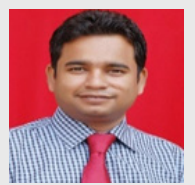

Dr. Pankaj Kumar currently working as Assistant Professor in the Department of Pharmaceutical Chemistry at NGSM Institute of Pharmaceutical Sciences, Mangalore, Karnataka. He has more than 10 years of experience in teaching and research, his area of interest is computational chemistry and synthetic chemistry.

Dr. Praveen Thaggikuppe Krishnamurthy, Professor and Head, in the Department of Pharmacology at JSS college of Pharmacy, Ooty, He has more than 17 years of experience in teaching and research. His areas of research interest includes, Computer Aided Drug Discovery, Metabolic disordersDiabetes Mellitus, Herbal drug research and Preclinical drug development. He has published 45 research papers, a Book chapter and successfully filed an Indian patent. He is a reviewer for many National and International Journals.

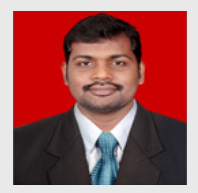

Vijay Kumar basically a Pharmacologist working in as Assistant Professor at NGSM Institute of Pharmaceutical Sciences, NITTE (Deemed to be University), Mangaluru, Karnataka. He is experienced in conducting animal experiments in new models for pharmacological screening, efficient in developing labs for animal experimentation and animal house facility and believes in interdisciplinary research. Published more than 30 articles in national and international journals with impact factor and presented more than 35 paper international and national conferences. His research areas are Preclinical Drug Development, Diabetes and Metabolic Disorders, Herbal Drug Research, Neurodegenerative disorders.

Cite this article: Shetty $\mathrm{CR}$, Bhat KI, Kumar A, Kumar P, Krishnamurthy PT, Merugumolu VK. Synthesis, in-silico Studies and Evaluation of Anticancer Activity of Some Novel Benzothiazole Substituted 4-Thiazolidinones. Indian J of Pharmaceutical Education and Research. 2020;54(4):1121-32. 